\title{
Analysis and Design of Automated Electric Power Generation Unit from Domestic Waste
}

\author{
Muthu Raman V, Muthuvel AMR, Narayan Koushik C, Priyanka K. Maniyal
}

\begin{abstract}
Use of bio-degradable waste has been effective in power production. Bio-degradable waste undergoes a process of anaerobic digestion after which they are subjected to Induction Heating. Methane gas is produced, which then powers the methanol fuel cells. The Proposed technique ensures complete safety; detectors and valves are installed at various places to detect any minor or major anomalies. All these detectors and valves are coordinated and regulated by a main controller (PLC).
\end{abstract}

Index Terms - Bio-degradable waste, Anaerobic digestion, Cyclo-converters, Induction Heating, Methanol Fuel Cell, Power System Control.

\section{INTRODUCTION}

The spurt in population explosion globally has resulted in severity of energy crisis. Our dependency and usage of coal has dragged it to the point of extinction and has resulted in severe environmental pollution. The alternative to come over this adversity is to use renewable sources. Many proposed techniques in the past, have not used these resources to their fullest potential. A source which is readily available, socio-economic had to be used. This led to the idea of generating electric power from domestic waste incorporating induction heating. This proposed technique ensures complete utilization of domestic waste, with a meager amount of effluents being emanated into the atmosphere. This process does not involve any sophisticated mechanism and ensures complete safety. This method of power production paves way to less diligence and can be produced in the place where we reside.

\section{Analysis of Domestic Waste Production}

On an average every human being disposes off, $345.6^{[1]}$ liters of waste material (solid and liquid) into the sewage (A slurry of bacteria and undigested food) everyday. This waste consists of organic matter such as carbohydrates, proteins and lipids. This quantity of everyday sewage consists of 0.6 liters faecal matter (semi-solid matter) and 345 liters liquid waste. So, in a family of four persons, everyday $345.6^{*} 4=1382.4$ liters of waste material is approximately disposed off into the sewage. These 1382.4 liters of wastes can be effectively utilized to generate Electric Power. (Waste produced varies globally)

\section{ElECTRIC POWER GENERATION USING DOMESTIC WASTE}

The plant layout and flow chart of this process is shown in fig. 1 and fig. 2 respectively.

\subsection{Space Allocation}

The minimum space required for induction heating unit and power generation for a $60 * 40$ square feet (normal size for 4 persons) house is $10 * 10=100$ square feet. The dimensions of the unit depend on the number of people residing in the house and not on the area of the house. The space allocated for each process is shown in the fig. 4 , where $8 * 5$ square feet is for induction heating process, $2 * 10$ square feet is for cooling chamber, $8^{*} 5$ square feet is for power generation using methanol fuel cells.

\subsection{Dumping of Waste}

The stored waste is acted upon by anaerobic bacteria for a period of 15 days. Anaerobic digestion ${ }^{[2]}$ process involves four stages namely, hydrolysis, acidogenesis, acetogenesis, methanogenesis as shown in the fig. 3. Polymers are broken into smaller units called monomers during hydrolysis. Carbonic acid is formed in acidogenesis and acetic acid in acetogenesis with carbon di-oxide and ammonia as the by-products of these processes. Acetic acid is converted into methane in the methanogenesis. Anaerobic digestion is continuous, mesophilic, low solid, single stage process. This process produces a small amount of methane gas which is insufficient to drive the methanol fuel cells. Hence, Induction Heating is employed to heat this waste to produce more quantity of methane gas. The methane gas produced is fed to the fuel cells.

Muthu Raman.V is with StJosephs college of engineering as a student of final year electrical and electronics engineering department, Chennai, Tamil nadu, INDIA. (ph: +91-9843973303, mail-id: muthusa186@gmail.com)

Muthuvel.AMR is with StJosephs college of engineering as a student of final year electrical and electronics engineering department, Chennai, Tamil nadu, INDIA.(mail-id: velmuthu23@gmail.com)

Narayan Koushik.C is with StJosephs college of engineering as a student of final year electrical and electronics engineering department, Chennai, Tamil nadu, INDIA.(mail-id: narayankoushik@aol.in)

Priyanka.K.Maniyal is with PSG college of technology as a student of electrical and electronics engineering department, Coimbatore, Tamil nadu, INDIA. (mail-id: priyankakmaniyal@yahoo.co.in) 


\section{PLANT LAYOUT}

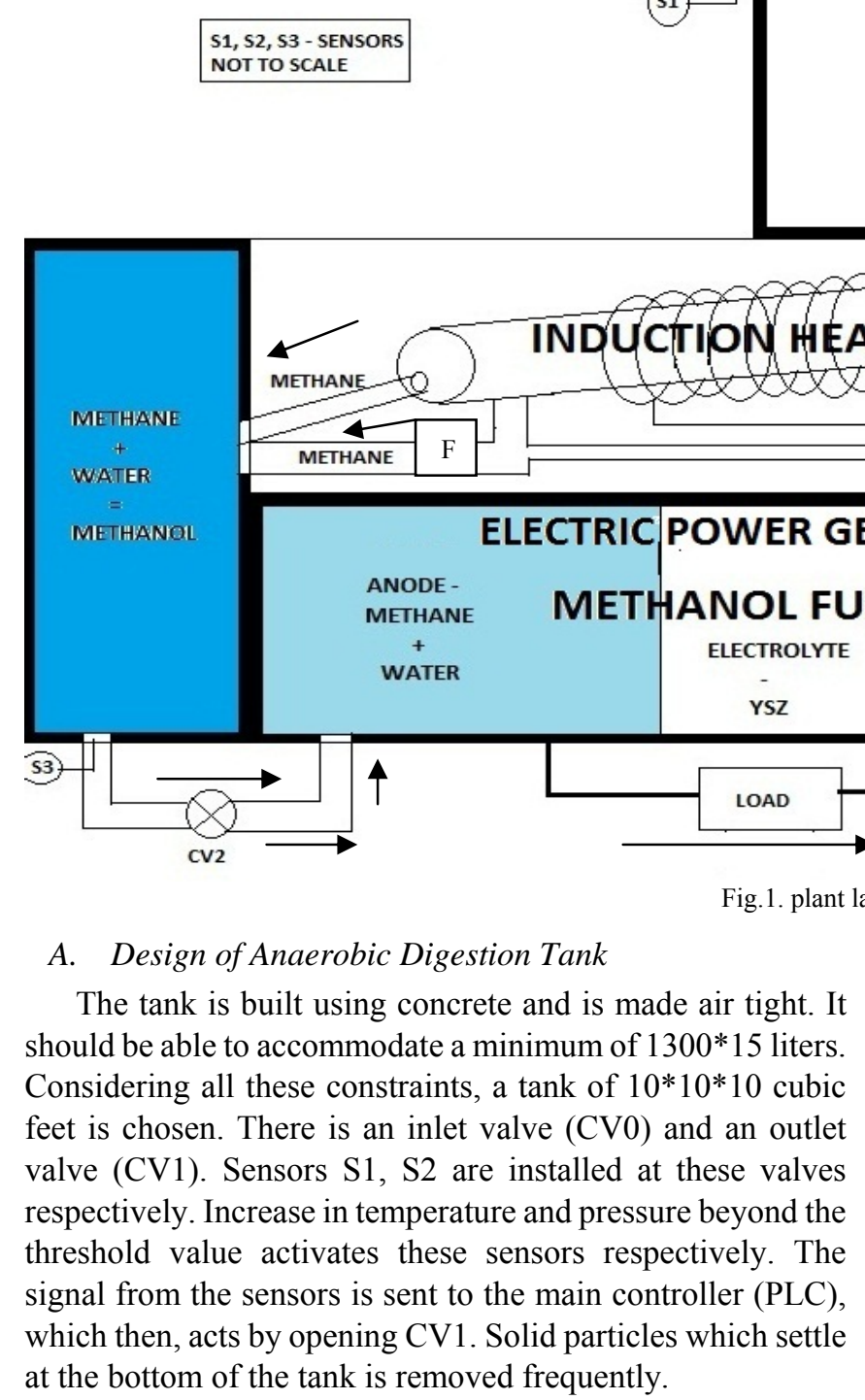

\subsection{Installation of Induction Heating system}

Induction Heating system is a non-contact heating process in which the localized heat is produced by the custom designed coils. An induction heater of $10 \mathrm{~kW}$ capacity is proposed in this project.

The coil is wound around a long, hollow steel pipe. Waste is made to flow through the steel pipe using feed pump, and induction heating begins. This steel pipe has two outlets, one for the solid waste (sludge) and the other for gas as shown in the fig. 1

\section{A. Design of Induction Heating system ${ }^{[3]}$}

Design of induction heater coils is very important, because waste flowing through the steel pipe should be maintained at a temperature of $29.5^{\circ} \mathrm{C}-35^{\circ} \mathrm{C}$. The coil is wound around the steel pipe. Multi-turn coils with large diameter of steel pipe should be used. In an induction heater, the output power is expressed as,

$$
\mathrm{P}=\Pi \text {.d.h.H } \mathrm{H}^{2} . \mathrm{C} . \mathrm{F}\left(\mu_{\mathrm{o}}, \mu_{\mathrm{r}} . \Pi \text {. f . } \rho\right)^{\wedge}(1 / 2)
$$

Where, H-magnetic field intensity

$$
\text { f-frequency }
$$

C-correction factor

F-power transmission factor

P-output power

The heat penetration depth in this machine is given by,

$$
\delta=(\rho /(\Pi \mu \mathrm{f}))^{\wedge}(1 / 2)
$$

Where, $\rho$-resistivity $\mu$-magnetic permeability

The efficiency of the machine is given by,

$$
\eta=\left(\mathrm{P} /\left(\mathrm{P}+\mathrm{P}_{\mathrm{i}}\right)\right)
$$

$\mathrm{P}$-power induced in the load

$\mathrm{P}_{\mathrm{i}}$-power dissipated in the inductor

From the equations (1), (2), (3) it is clearly shown that, the output power is directly proportional to frequency and magnetic field intensity, the heat penetration depth is inversely proportional to frequency. This implies that, for better heating of waste till the center of the pipe, the best choice of frequency has to be maintained. Hence, a closed loop control is employed for the cyclo-converter.

\subsection{Cooling Chamber:}

Methane obtained from one of the outlets of the steel pipe is converted into methanol by hydrolysis. Sludge is collected from other outlet which can be used as manure. This process is carried out in a sealed concrete wall, so as to arrest the gas leakage as shown in the Fig. 1. As a precautionary measure a sensor is installed ( $\mathrm{S} 3$ ). In the event of a leakage, a signal is sent to the main controller (PLC). Controller reacts by closing controller valve (CV1). It is opened after rectifying the leakage problem. 


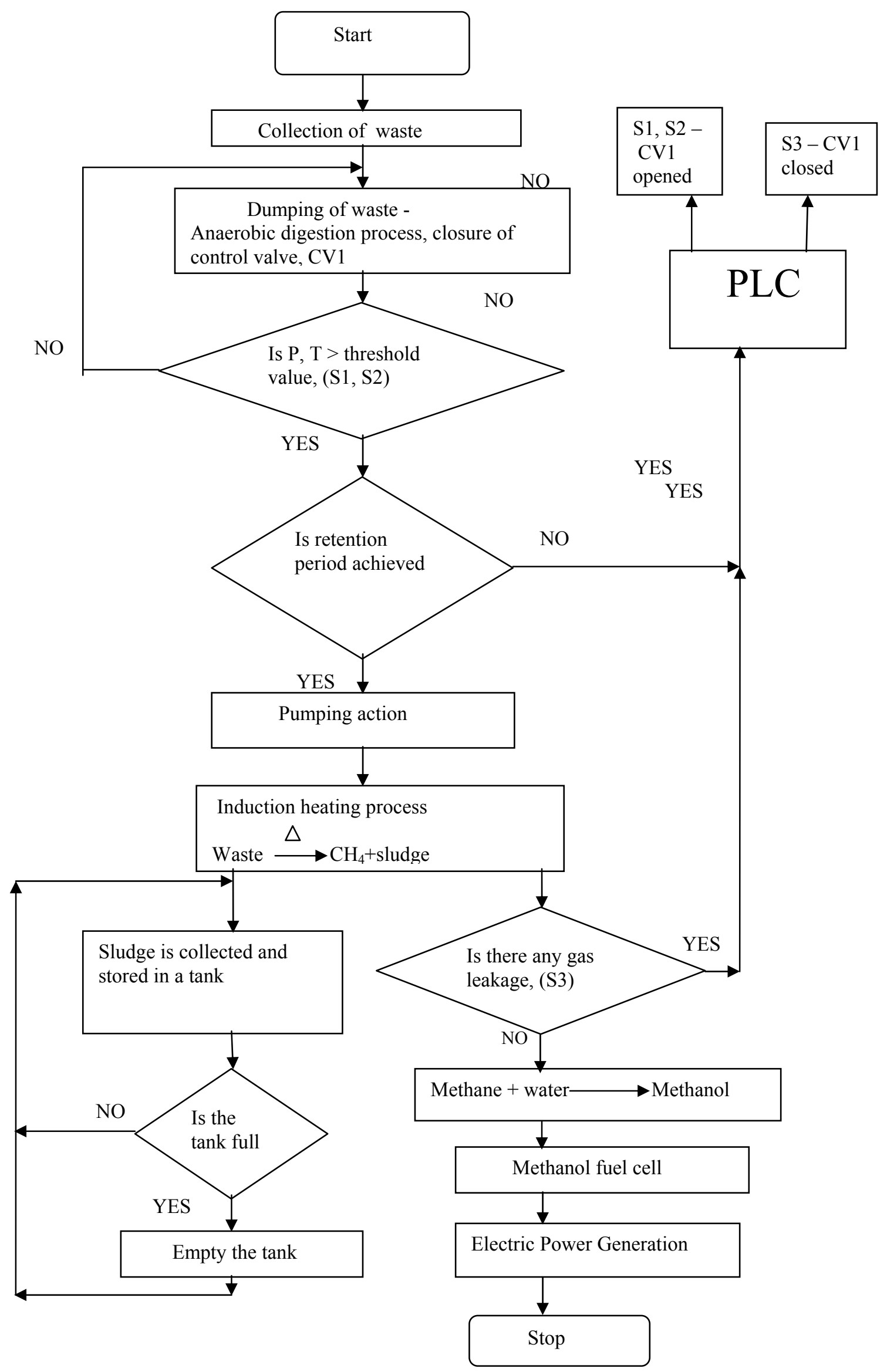

Fig.2. Flow chart depicting various stages of EPG unit 


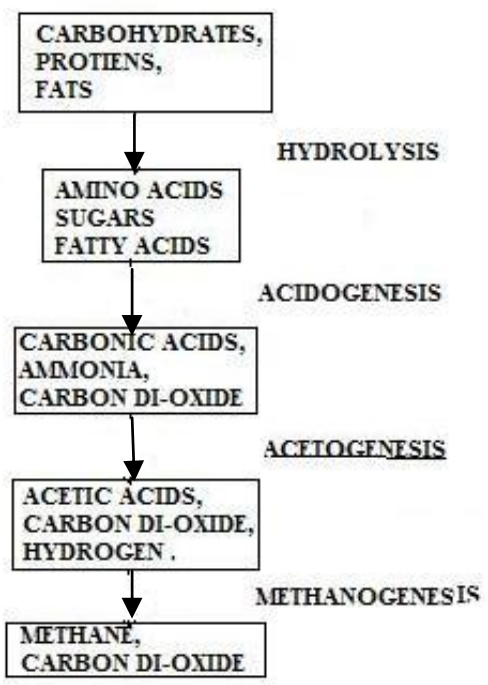

Fig.3.Sequence of processes in anaerobic digestion

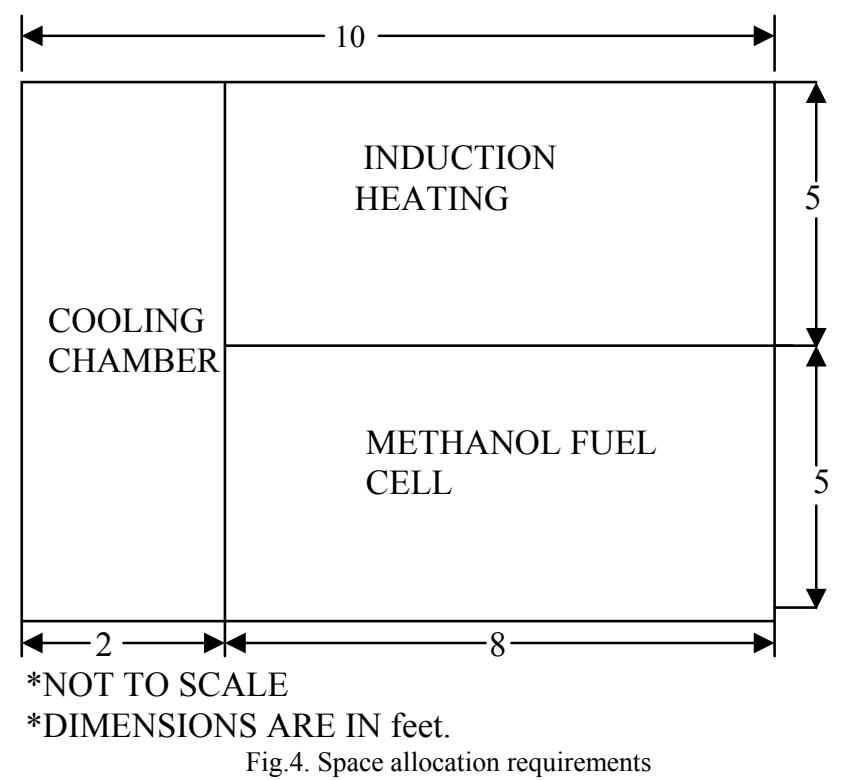

\subsection{Power generation from Methanol Fuel Cell ${ }^{[4]}$}

Methanol obtained from the cooling chamber will act as the anode, reacts with water to give hydrogen ions and electrons in methanol fuel cell. Yttria Stabilized Zirconia (YSZ) is used as electrolyte, which allows only hydrogen ions to pass through. Hence the electrons travel externally through the connected load and reach the cathode to complete the circuit as shown in the fig. 1 . The reactions taking place in the fuel cell are,

Anode reaction

Cathode reaction:

$$
\mathrm{CH}_{3} \mathrm{OH}+\mathrm{H}_{2} \mathrm{O} \rightarrow \mathrm{CO}_{2}+6 \mathrm{H}^{+}+6 \mathrm{e}^{-}
$$

Overall cell reaction:

$$
3 / 2 \mathrm{O}_{2}+6 \mathrm{H}^{+}+6 \mathrm{e}^{-} \rightarrow 3 \mathrm{H}_{2} \mathrm{O}
$$

$$
\mathrm{CH}_{3} \mathrm{OH}+3 / 2 \mathrm{O} 2 \rightarrow \mathrm{CO}_{2}+2 \mathrm{H}_{2} \mathrm{O}+\text { electrical energy }
$$

By this, the so produced methanol is converted into electric power.

\section{Electric PoWER GENERATION ANALYSIS}

i. The estimation of the domestic wastage disposed into a septic tank for a period of 24 hours is as follows:

FAECAL MATTER
1 person disposes 0.6 liters.

Approximately for 4 persons $\approx 2.0$ liters

LIQUID WASTE

1 person produces 345 liters.

Approximately for 4 persons $\approx 1300$ liters

ii. The estimation of domestic waste disposed and electric power generation for a period of 15 days is as follows:

Approximately $1300^{*} 15 \approx 19500$ liters of waste is disposed

1 liter of waste produces 28.3 liter of methane gas (minimal approximation)

Approximately 28.3 liters of gas produces 0.3 liters of methanol.

$19500 * 0.3 \approx 5850$ liters of methanol is produced.

1 liter of methanol may generate $1 \mathrm{~W}$ (minimum value)

5850 liters of methanol may generate $5.85 \mathrm{KW}$

In this analysis $10 \mathrm{KW}$ induction heater is proposed. The total power consumed for the Electrical Power Generation (EPG) by the heating system and other equipment is follows,

$1.5 \mathrm{KW}$ for 15 days,

$3.0 \mathrm{KW}$ for a month.

Hence, the normal gain is $5.8-3.0=2.85 \mathrm{KW}$ which can be utilized for domestic purpose.

\section{MERITS AND APPLICATIONS}

The benefits are, Eco friendly environment, Byproduct (sludge) can be used as manure, Waste management, Unsophisticated mechanism. This setup uses less space in comparison with others. Automation provided through advanced technologies (PLC), which reduces the fault and leakage. This design can also be adopted in trains, hostels and hospitals.

\section{CONCLUSION}

This technique provides generation of Green power (5.8KW/month) along with a useful byproduct (sludge). Apart from these, methanol produced in this process can be used for fuelling vehicles, which reduces the dependency on crude oil. It also balances the adversity in power because of spurt in population. Use of modern technology reduces real time errors.

\section{ACKNOWLEDGMENT}

Special thanks to Dr.K.Manjunath BE., ME., Ph.D, Dr.B.S.Mohanty B.Sc. Engg., M.Tech, Ph.D, Adam Ali Shah $\mathrm{BE}, \mathrm{ME}$, teaching and non teaching staff of St.Josephs college of engineering (Affiliated to ANNA University, Chennai, Tamil nadu, INDIA) for guiding us at every step for the completion of the paper.

\section{REFERENCES}

[1] USGS, "Water science for schools- Water Q\&A", water use at home Q3. [Online] Available: http://ga.water.usgs.gov/edu/qahome.html

[2] Friends of Earth, "Briefing Anaerobic Digestion" (2004) Retrieved 17.08.07. [Online] Available: Anaerobic digestion Briefing Paper,www.foe.co.uk.

[3] DaWei Induction Heating machine Co., Ltd, “Technology- Properties of Induction Heating" [Online] Available: http://www.gpgyjr.com.cn/New-35.html

[4] Fuel Cell Basics, "Types of fuel cells-direct methanol fuel cells" [Online] Available: http://www.fctec.com/fctec_types_dmfc.asp 